\title{
IDENTIIFKASI PROTEIN IMUNOGENIK CHLAMYDIA PNEUMONIAE TERHADAP SERUM PENDERITA INFARK MIOARD AKUT
}

\section{IDENTIFICATION OF IMMUNOGENIC PROTEIN OF CHLAMYDIA PNEUMONIAE TO ACUTE MYOCARDIAL INFARCTION PATIENTS SERUM}

\author{
Sri Murwani, Dwi Yuni Nur Hidayati \\ Laboratorium Mikrobiologi Fakultas Kedokteran Universitas Brawijaya Malang
}

\begin{abstract}
Chlamydia pneumoniae is human respiratory tract pathogen and recently investigated as pathogen causing atherosclerosis and acute myocardial infarction (AMI). This research was carrier out to detect protein pattern of $\mathrm{C}$. pneumoniae, and to study it relation to AMI through detection of immunogenic protein. Design research was laboratory observational and analyzed descriptively. The subject was C. pneumoniae. Protein pattern the bacteria was detected by electrophoresis method, and to detect the immunogenic protein was done immunoblotting. Serum was obtained from AMI patients in Saiful Anwar and Lavallette hospitals. The result showed, protein pattern C. pneumoniae was protein with molecular weight 117, 107, 97, 91, 86, 61, 58, 52, 46, 44, 34, 23, 19, 9, 5, $4 \mathrm{kDa}$. Immunogenic proteins vary between AMI patients was 117, 107, 86, 61, 58, 52, 46, 44, $34 \mathrm{kDa}$. Non immunogenic proteins were 97, 91, 23, 19, 9, 5 and 4 $\mathrm{kDa}$. Protein $61 \mathrm{kDa}$ react to all of patient's serum. It was concluded, C. pneumoniae have protein fractions 117, 107, 97, $91,86,61,58,52,46,44,34,23,19,9,5$, and $4 \mathrm{kDa}$. Immunogenic proteins vary between AMI patients was 117, 107, $86,61,58,52,46,44,34 \mathrm{kDa}$, and $61 \mathrm{kDa}$ was the immunodominant protein. The result proved $\mathrm{C}$. pneumoniae as causative agent of atherosclerosis and acute myocardial infarction, in Indonesia particularly.
\end{abstract}

Key words: C. pneumoniae, immunogenic, AMI

\section{PENDAHULUAN}

Sejak tahun 1988 infeksi C. pneumoniae dihubungkan dengan patogenesis aterosklerosis dan manifestasi klinisnya seperti penyakit jantung koroner, stenosis arteri carotid, aneurisma aortic, klaudifikasi dan stroke. Studi seroepidemiologi menunjukkan, bahwa pada penderita aterosklerosis titer antibodnya terhadap C. pneumoniae dua atau lebih tinggi dibanding individu normal. Hubungan tersebut didukung ditemukannya organisme pada atheroma $(1,2)$, yaitu ditemukan dalam sel endotelial, makrofag dan (smooth-muscle cell) SMC plak aterosklerotik. Peran C. pneumoniae pada patogenesis aterosklerosis ditunjukkan adanya respons seluler yang dihubungkan dengan inflamasi, proliferasi sel dan remodeling jaringan (3)

Chlamydia pneumoniae dapat menginfeksi sel endothelial manusia secara in vitro dan menstimulasi ekspresi selectin-E, (Intracelluler Adhesion Molecule) ICAM-1, (Vascullar Adhesion Molecule) VCAM-1. Hal tersebut diduga merupakan faktor mekanisme patogenik lokal C. pneumoniae dalam menyebabkan gangguan inflamasi vascular, termasuk aterogenesis $(1,2)$. Menurut SE. Epstein (disitasi oleh Sherer dan Shoenfeld, 2001), C. pneumoniae dapat menginfeksi secara langsung dinding pembuluh darah (4).

Jurnal Kedokteran Brawijaya, Vol. XXIII, No. 2, Agustus 2007 Korespondensi: Sri Murwani; Lab. Mikrobiologi FK Unibraw Malang; Jl. Veteran Malang; Telp: 580993 ext. 111
Semua spesies Chlamydia mempunyai (Lipopolysaccharide) LPS yang bersifat genus-specific, yang berada pada permukaan sel (Elementary Body) EB dan (Reticulate Body) RB (5). Lipopolisakarida tersebut dapat menginduksi diferensiasi monosit menjadi makrofag, dan meningkatkan kemampuan fagositosis (6), selain itu dapat menyebabkan terbentuknya foam cells makrofag secara in vitro, apabila dipapar dengan (Low Density Lipoprotein) LDL. Endotoksin bakteri dan pelepasan TNF- $\alpha$ dapat mengganggu pelepasan nitric-oxide dan prostacyclin, yang berlanjut terjadinya perubahan sel endotel. Kerusakan sel endotel dapat menyebabkan absorbsi LDL yang teroksidasi, menyebabkan kondisi patologis sel endotel, menginduksi rekrutmen sel mononuklear, mediator inflamsi dan growth-factor. Induksi respons fibroproliferatif SMC pembuluh dan terbentuknya plak aterosklerotik (7).

Selain itu (Heat Shock Protein 60) HSP60 C. pneumoniae (cHSP60) mempunyai konstribusi terjadinya aterosklerosis, yaitu menyebabkan teroksidasinya LDL (8). Dikatakan (chlamydial Heat Shock Protein 60) cHSP60, homolog dengan protein vaskuler manusia, sehingga terjadi antigenic mimicry, cross-reaction dan menyebabkan luka pada sel endotel vaskuler (9). cHSP60 ditemukan pada karotid atheroma manusia (10).

Hal paling penting pada patogenesis (Infark Miokark Akut) IMA adalah hancurnya plak dan terbentuknya thrombus. Ruptur plak sering terjadi pada daerah dekat shoulder 
plak, yang mempunyai fibrous cap tipis dan core yang kaya lipid. Integritas struktural dinding arteri terutama tergantung pada extracellular matrix (ECM). Degradasi kolagen fibriler akan menurunkan kemampuan fibrous cap menahan stress mekanik. Famili (Materix Metalloproteinase) MMP merupakan enzim yang memegang peran penting terhadap integritas jaringan pada lesi aterosklerotik, dapat menyebabkan ruptur plak dan unstable coronary syndrome (11).

Smooth-Muscle Cell vaskuler manusia merupakan sel yang paling banyak pada dinding pembuluh arteri, dan pada kultur mengekspresikan MMP-2 secara konstitutif dan MMP-1, MMP-3, MMP-9 pada level yang tidak memberikan arti. Pada lesi aterosklerotik, SMC mengekspresikan keempat MMP tersebut sebagai protein yang immunoreactive (11). Huang et al (1999), mendemonstrasikan MMP-1, MMP-9 dan MMP-3 yang diekspresikan oleh sel-sel di ateroma, yang meliputi luminal, neovascular endothelial cells, makrofag, SMC. Ketiga MMP tersebut tidak ditemukan pada arteri normal. Dikatakan MMP-1 paling dominan dan mengawali rusaknya kolagen, pada $\mathrm{pH}$ normal terutama kolagen tipe 1 (12). C. pneumoniae menginduksi ekspresi 92Kda gelatinase oleh makrofag. Stimulasi produksi $92 \mathrm{kDa}$ gelatinase oleh monocyte-derived macrophage oleh $\mathrm{C}$. pneumonia melalui beberapa protein chlamydia yaitu Omp2, MOMP dan HSP60 (13).

Hasil-hasil penelitian yang menyebutkan adanya keterlibatan kuman $C$. pneumoniae pada aterosklerosis dan IMA diperkuat dengan hasil penelitian sebelumnya, yaitu penelitian seroepidemiologi $C$. pneumoniae pada penderita IMA yang dihubungkan faktor resiko IMA lainnya (hipertensi, merokok, usia, jenis kelamin) dan kemungkinan adanya infeksi multipel dengan bakteri-bakteri lain yang diduga dapat menyebabkan IMA (Cytomegalovirus, Helicobacter pylori, Phorphyromonas gingvalis, Streptococcus mutans). Hasil penelitian menunjukkan, bahwa dari 27 pasien IMA dari Rumah Sakit Saiful Anwar Malang dan Rumah Sakit Lavalette Malang, menunjukkan bahwa 25 pasien (92,59\%) terinfeksi C. pneumonaie dan sebagian besar terjadi infection burden. Infeksi $C$. pneumoniae tersebut tidak disertai dengan faktor resiko lainnya (merokok, hipertensi, hiperkolaterol dan diabetes) (14).

Berdasar pustaka-pustaka yang ada dan penelitian pendahuluan yang telah lakukan, dapat disimpulkan bahwa ada hubungan antara C. pneumoniae dengan IMA. Pada penelitian ini dilakukan karakterisasi profil protein $C$. pneumoniae (berdasar berat molekul) dan dicari proteinprotein yang imunogenik pada penderita IMA. Harapan lebih lanjut protein imunogenik tersebut dapat digunakan sebagai diagnosa dini individu terinfeksi $C$. pneumoniae terhadap resiko terkena IMA.

Penelitian ini bertujuan untuk mendeteksi profil protein C. pneumoniae dan imunogenisitasnya pada pen- derita IMA. Sedangkan manfaat penelitian ini adalah sebagai dasar pengembangan penelitian tentang $C$. pneumoniae, dan pengembangan ilmu pengetahuan tentang hubungan penyakit-penyakit infeksi dengan IMA.

\section{METODE}

\section{Rancangan penelitian}

Rancangan penelitian adalah observasional laboratorik dan dianalisa secara analitik diskriptif. Sampel penelitian adalah C. pneumoniae strain TWAR.

\section{Bahan}

Antigen C. pneumoniae diperoleh dari United States Biological (Catalog No. C4250-28), sedang serum darah penderita di peroleh dari RS. Saiful Anwar dan RS. Lavalette Malang. Bahan lain yang dipergunakan antara lain akrilamid, tris base, biru komasik, methanol, TEMED, sample buffer, SDS, membran nitroselulose, konjugat, substrat, bovine serum albumin, high molecular weight protein marker, $\mathrm{Na}_{2} \mathrm{HPO}_{4}, \mathrm{NaH}_{2} \mathrm{PO}_{4}, \mathrm{NaCl}$ dan akuades.

Alat yang diperlukan adalah 1 unit alat elektroforesis, 1 unit alat elektrobloting, heparinized venoject. Tempat penelitian berada di Laboratorium Sentral Biomedik Fakultas Kedokteran Universitas Brawijaya, dan Laboratorium Mikrobiologi Fakultas Kedokteran Universitas Brawijaya

\section{Langkah-langkah penelitian}

Profil protein C. pneumoniae dideteksi menggunakan elektroforesis pada akrilamid $12,5 \%$. Deteksi reaktifitas protein C. pneumoniae pada penderita IMA menggunakan tehnik imunobloting. Metode yang digunakan adalah semidry immunoblotting.

\section{HASIL PENELITIAN}

Whole cell C. pneumoniae dielektroforesis pada akrilamid $12,5 \%$. Hasil elektroforesis menunjukkan fraksifraksi protein $C$. pneumoniae dengan berat molekul (Gambar 1): 117.000; 107.000; 97.000; 91.000; 86.000; 61.000; 58.000; 52.000; 46.000; 44.000; 34.000; 23.000; 19.000; 8.000; 5.000; 4.000 Dalton (Da). Diperoleh satu protein mayor dengan berat molekul $61.000 \mathrm{Da}$ (perhitungan berat molekul menggunakan regresi eksponensial).

Hasil elektroforesis kemudian direaksikan dengan antibodi penderita IMA untuk melihat sifat imunogenisitas protein. Selama 10 bulan penelitian, diperoleh 19 serum penderita IMA dari RS. Saiful Anwar dan RS. Lavalette Malang. Diagnosis IMA ditentukan berdasar anamnesis, pemeriksaan klinis, EKG dan tes darah (CPK; CKMB; dan troponin). 


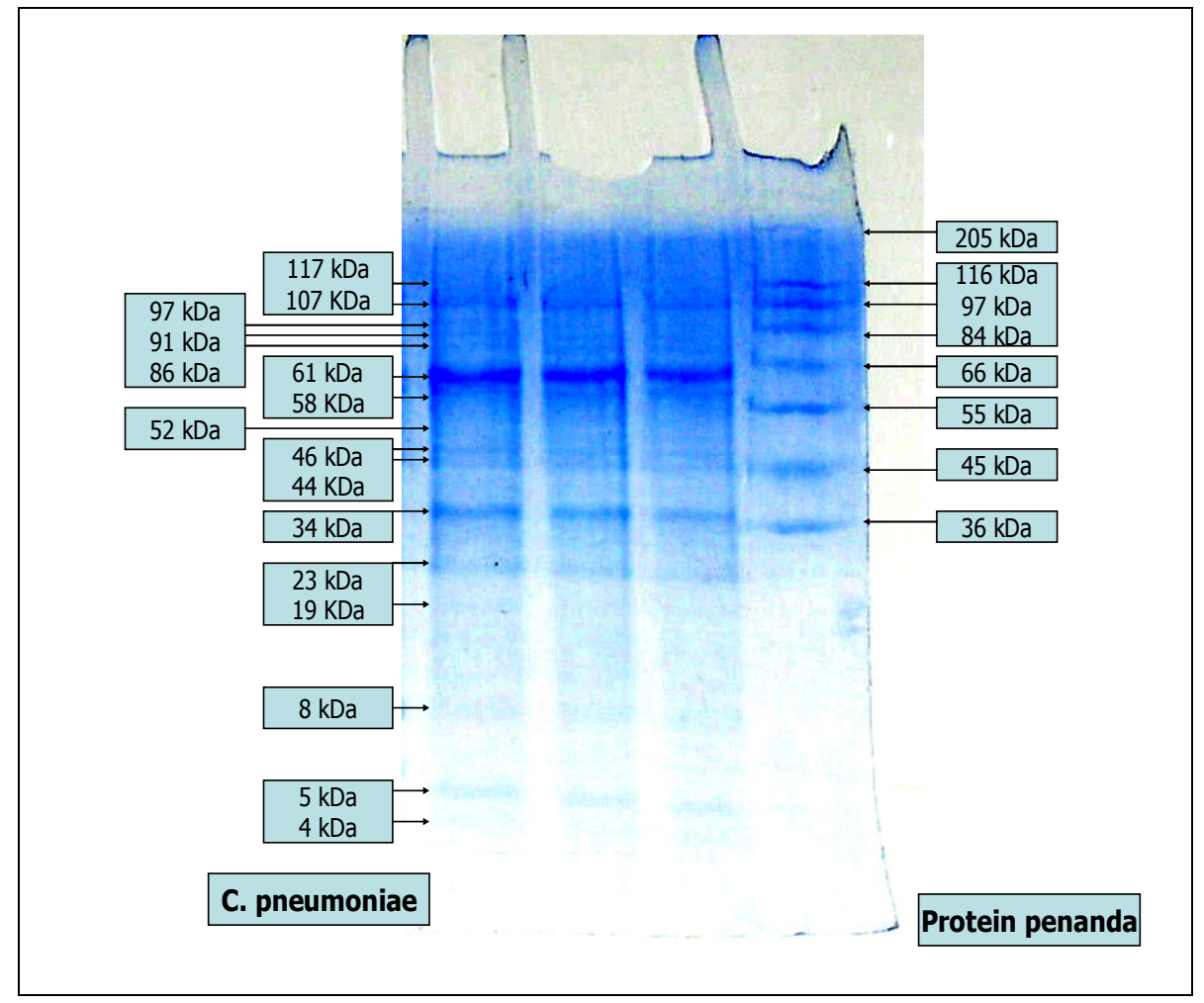

Gambar 1. Hasil elektroforesis C. pneumoniae (lajur 1, 2, 3). Lajur 4, protein penanda

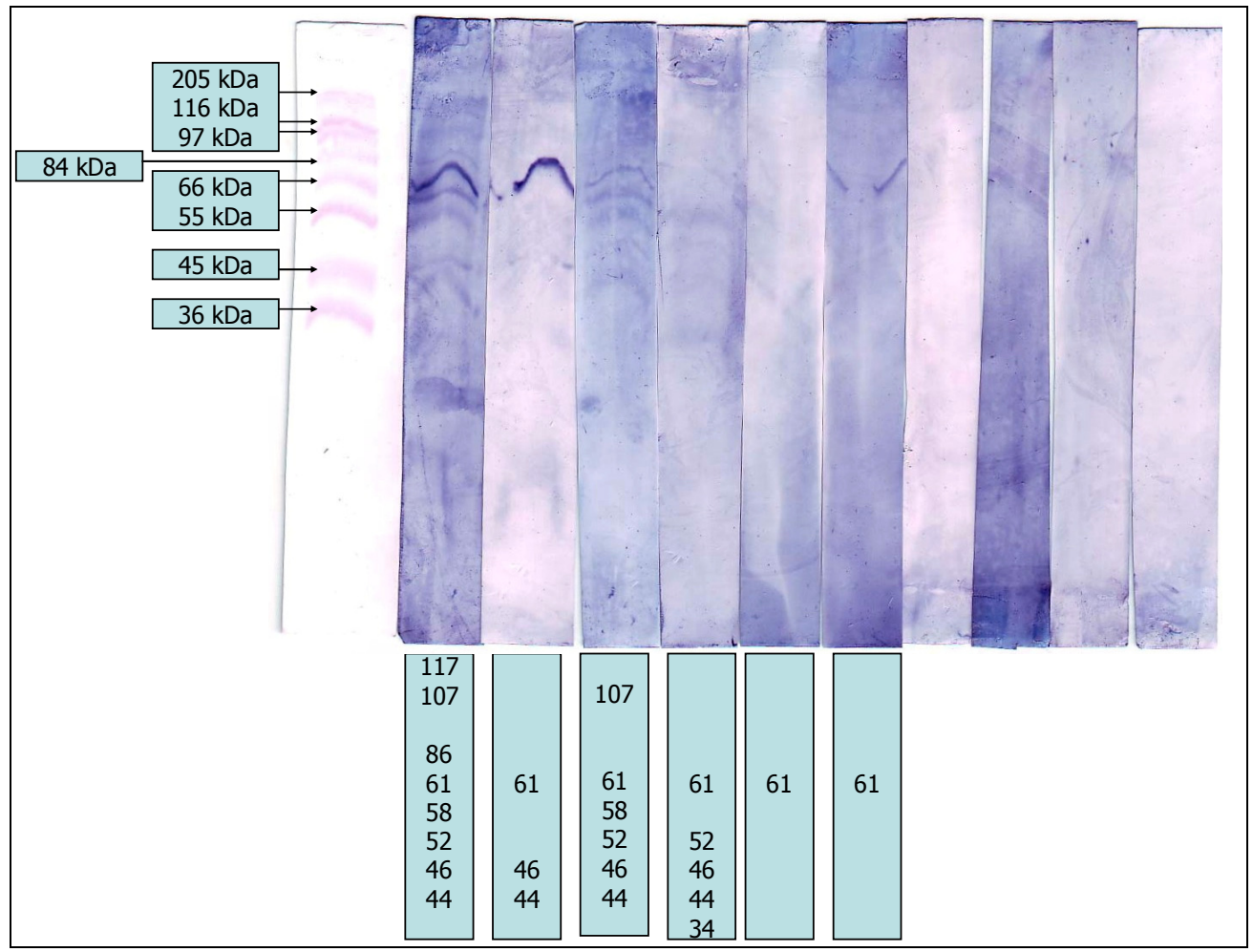

Gambar 2. Hasil imunobloting fraksi protein C. pneumoniae terhadap antibodi penderita IMA 


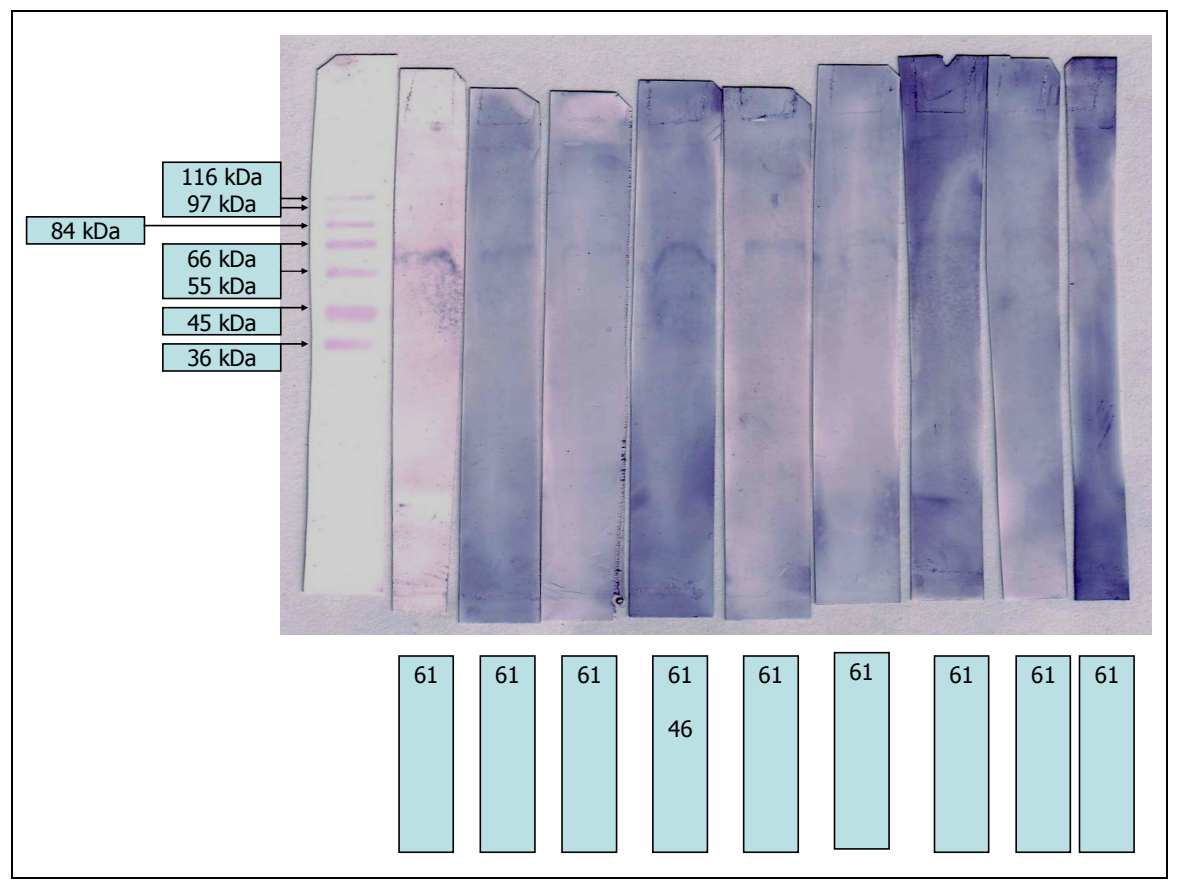

Gambar 3. Hasil imunobloting fraksi protein C. pneumoniae terhadap antibodi penderita IMA

Tabel 1. Hasil imunobloting antara protein C. pneumoniae terhadap antibodi penderita IMA

\begin{tabular}{|c|c|c|}
\hline \multicolumn{3}{|c|}{ Nomor Serum Penderita IMA Fraksi Protein C. pneumoniae (Dalton) yang Bereaksi Positif terhadap Serum Penderita IMA } \\
\hline 1 & \multicolumn{2}{|c|}{$117.000,107.000,86.000,61.000,58.000,52.000,46.000,44.000$} \\
\hline 2 & 61.000, & $46.000,44.000$ \\
\hline 3 & 107.000, & $52.000,46.000,44.000$ \\
\hline 4 & 61.000, & $52.000,46.000,44.000,34.000$ \\
\hline 5 & 61.000 & \\
\hline 6 & 61.000 & \\
\hline 7 & Tidak bereaksi & \\
\hline 8 & Tidak bereaksi & \\
\hline 9 & Tidak bereaksi & \\
\hline 10 & Tidak bereaksi & \\
\hline 11 & 61.000 & \\
\hline 12 & 61.000 & \\
\hline 13 & 61.000 & \\
\hline 14 & 61.000, & 46.000 \\
\hline 15 & 61.000 & \\
\hline 16 & 61.000 & \\
\hline 17 & 61.000 & \\
\hline 18 & 61.000 & \\
\hline 19 & 61.000 & \\
\hline
\end{tabular}


Dari 19 serum tersebut yang menunjukkan reaksi positif terhadap fraksi protein $C$. pneumoniae sebanyak 15 (Gambar 2 dan Gambar 3). Fraksi protein yang bereaksi variatif di antara penderita IMA. Fraksi protein tersebut adalah protein $117.000,107.000,86.000,61.000,58.000$, $52.000,46.000,44.000,34.000 \mathrm{Da}$. Sedang yang tidak bereaksi adalah protein 97.000, 23.000, 19.000, 8.000, 5.000 , dan $4.000 \mathrm{Da}$. Protein 61.000 Da selalu reaktif pada serum setiap penderita (Tabel 1).

\section{DISKUSI}

Hasil elektroforesis diperoleh hasil fraksi-fraksi protein C. pneumoniae dengan berat molekul: 117.000; 107.000; 97.000; 91.000; 86.000; 61.000; 58.000; 52.000; 46.000; 44.000; 34.000; 23.000; 19.000; 8.000; 5.000; 4.000 Dalton (Da). Menurut Vehmaan-Kreula et al. (2001), pada bagian luar elementary body (EB) C. pneumoniae mengandung protein struktural yang kaya sistein, dengan berat molekul 98, 60-doublet, 39,5 dan 15,5 kDa. Protein $60 \mathrm{kDa}$ merupakan protein mayor, yang sebenarnya terdiri dari 2 fragmen protein, yaitu protein omp-2 dan cHSP60 (13).

Dari hasil penelitian ini, yang merupakan protein mayor adalah $61 \mathrm{kDa}$, diduga protein tersebut sebenarnya adalah protein $60 \mathrm{kDa}$ C. pneumonie. Hal ini didukung oleh hasil imunobloting, bahwa protein $61 \mathrm{kDa}$ merupakan antigen yang paling imunodominan. Akan tetapi untuk meyakinkan diperlukan uji lebih lanjut, misalnya dengan imunobloting protein tersebut terhadap antibodi monoklonal anti-60 kDa. Vehmann-Kreula et al., (2001), menambahkan bahwa protein $60 \mathrm{kDa}$ merupakan outer membrane protein2 (omp2) membran luar chlamydia, dan merupakan imunogen utama C. pneumoniae (13). Ciervo et al. (2002), mengatakan bahwa protein $60 \mathrm{kDa}$ merupakan protein proinflamatori dan bersifat sangat imunogenik (15).

Bereaksinya fraksi protein C. pneumoniae dengan antibodi penderita memperkuat dugaan bahwa $C$. Pneumoniae dapat menimbulkan aterosklerosis dan IMA. Hal ini didukung dari hasil penelitian pendahuluan yang peneliti lakukan (Murwani dkk, 2004), tentang studi seroepidemiologi C. pneumoniae pada penderita IMA dan hubungannya dengan faktor resiko konvensional dan burden infection. Hasil penelitian pendahuluan tersebut menunjukkan, bahwa dari 27 penderita IMA positif mempunyai IgG terhadap $C$. pneumoniae.

Fraksi protein C. pneumoniae yang reaktif terhadap antibodi penderita IMA bervariatif. Hal tersebut kemungkinan dapat dihubungkan dengan kondisi penderita. Pada penderita yang sangat lemah atau immunocompromized, kemungkinan dapat meningkatkan patogenisitas, imunogenisitas relatif dari patogen yang menginfeksi.

Fraksi protein C. pneumoniae yang reaktif pada penelitian ini adalah protein $117.000,107.000,86.000$, $61.000,58.000,52.000,46.000,44.000$ dan $34.000 \mathrm{Da}$. Protein $61 \mathrm{kDa}$ merupakan protein yang imunodominan. Kuo et al. (1995), meneliti profil protein beberapa isolat $C$. pneumoniae (TWAR) dan memperoleh hasil bahwa pada semua isolat ditemukan protein $39,5 \mathrm{kDa}$ yang analog dengan MOMP tetapi tidak imunodominan dan bereaksi silang dengan chlamydia spesies lainnya. Ditemukan juga protein 15,5, 60 dan $98 \mathrm{kDa}$. Penelitian lain menggunakan analisis imunobloting serum kelinci yang diimunisasi dan serum pasien yang terinfeksi $C$. pneumoniae, menemukan beberapa protein reaktif yaitu protein MOMP, protein 30,43 , 50, 60, 68 dan $75 \mathrm{kDa}$. Freidank et al. (disitasi oleh Kuo et al, 1995) menemukan protein dominan yang reaktif dengan berat molekul $54 \mathrm{kDa}$. lijima et al (disitasi oleh Kuo et al, 1995) menemukan protein imunodominan 43, 46 dan 53 $\mathrm{kDa}$. Dikatakan bahwa ketiga protein tersebut bersifat spesifik untuk $C$. pneumoniae (16).

\section{KESIMPULAN}

Dari hasil penelitian ini dapat disimpulkan:

1. Bereaksinya fraksi protein C. pneumoniae terhadap antibodi penderita IMA memperkuat dugaan bahwa $C$. pneumoniae dapat menyebabkan IMA

2. $C$. pneumoniae mempunyai fraksi-fraksi protein dengan berat molekul: 117.000; 107.000; 97.000; 91.000; 86.000; 61.000; 58.000; 52.000; 46.000; 44.000; 34.000; 23.000; $19.000 ; 8.000 ; 5.000 ; 4.000$ Dalton (Da).

3. Fraksi protein $C$. pneumoniae yang bereaksi dengan antibodi penderita IMA bervariasi, yaitu protein 117.000; $107.000 ; 86.000,61.000,58.000,52.000,46.000,44.000$ dan $34.000 \mathrm{Da}$.

4. Protein $61 \mathrm{kDa}$ bersifat imunodominan. Diduga protein tersebut merupakan omp-2.

\section{SARAN}

Hasil penelitian ini masih jauh dari sempurna, sehingga masih perlu perbaikan, misalnya:

1. Sampel serum perlu ditambah jumlah maupun tempat pengambilan, agar mendapat hasil yang dapat dipakai sebagai dasar penelitian selanjutnya.

2. Perlu dilakukan uji reaksi silang antigen $C$. pneumoniae terhadap patogen lainnya, untuk menghilangkan positif palsu. 


\section{DAFTAR KEPUSTAKAAN}

1. Campbell LA, Kuo C-C, Grayston JT. Chlamydia pneumoniae and Cardiovascular Disease. Emerging Infectious Disease, October-December 1998; 18(4).

2. Kaukoranta-Tolvanen SS, Ronni T, Leinonen M, Saikku P, Laitinen K. Expression of Adhesion Molecules on Endothelial Cells Stimulated by Chlamydia pneumoniae. Microb Pathog 1999; 21(5): 407-411

3. Rodel J, Woytas M, Groh A, Schmidt K-H, Hartmann M, Lehmannm, Straube E. Production of Basic Fibroblast Growth Factor and Interleukin 6 by Human Smooth Muscle Cells following Infection with Chlamydia pneumoniae. Infection and Immunity, 2000; 3635-3641

4. Sherer Y and Shoenfeld Y. Archieved Reports. Report on the Europen Atherosclerosis Society Workshop on Immune System in Atherosclerosis. 2001.http://www.rheuma21st.com/archives/shoenfeld immune sys atheroscleosis $\% 20$. html

5. Christiansen G, Boesen T, Hjerno K, Daugaard L, Mygind P, Madsen AS, Knudson K, Falk E, Birkelund S. Molecular biology of Chlamydia pneumoniae surface protein and their role in immunopathogenicity. Denmark: Department of Medical Microbiology and Immunology and Department of Molecular and Structural Biology, University of Aarbus, Lake Diagnostic, University Hospital Aarbus. 1999.

6. Yamaguchi H, Haranaga S, Widen R, Friedman H, Yamamoto Y. Chlamydia pneumoniae Infection Induce Differentiation of Monocytes into Macrophages. Infection and Immunity, 2002; 70(5): 2392-2398

7. Ngeh J and Gupta S. Chlamydia pneumoniae and Atherosclerosis: Causal or Coincidental Link?, ASM News, 2000; 66 (12)

8. Byrne $\mathrm{Gl}$ and Kalayoglu MV. Chlamydia pneumoniae and atherosclerosis: Link to diseases process. Madison: Department of Medical Microbiology \& Immunology, University of Wisconsin. 1999.

9. Mayr M, Metzler B, Kiechl S, Willeit J, Schett G, Xu Q, Wick G. Endothelial Cytotoxicity Mediated by Serum Antibodies to Heat Shock Proteins of Escherichia coli and Chlamydia pneumonia. Institute for Biomedical Aging Research, Austrian Academy Sciences Innsbruck; Department of Neurology, University Cinic, Innsbruck; Institute for General and Experimental Pathology, University of Innsbruck, Medical School, Innsbruck, Austria. E-mail IBA@oaeaw.ac.at

10. Kol A, Sukhova G.K, Lichtman, AH, Libby P. Chlamydial Heat Shock Protein 60 Localizes in Human Atheroma and Regulates Macrophage Tumor Necrosis Factor- $\alpha$ and Matrix Metalloproteinase Expressin. Circulation, 1998; 300-307.

11. Schoenbeck U, Mach F, Sukhova GK, Murphy C, Bonnefoy J-Y, Fabunmi RP, Libby P. Regulation of Matrix Metalloproteinase Expression in Human Vascular Smooth Muscle Cells by T Lymphocytes, A Role for CD40 Signaling in Plaque Rupture? Circulation Research, 1997; 81: 448-454.

12. Huang Y, Mironova M, Lopes-Virella MF. Oxidation LDL Stimulates Matrix Metalloproteinse-1 Expresion in Human Vascular Endothelial Cells. Atherosclerosis, Thrombosis, Vascular Biology, 1999;19:2640

13. Vehmaan-Kreula P, Puolakkainen M, Sarvas M, Welgus HG, Kovanen PT. Chlamydia pneumoniae Protein Induce Secretion of the 92-kDa Gelatinase by Human Monocyte-Derived Macrophages. Atheriosclerosis, Thrombosis, and Vascular Biology, 2001;21:ie

14. Murwani S, Muliartha K, Ali M, Purwanto, Susilowati IDA, Yuniarti, Nur'aini DD. Studi seroepidemiologi Infark Miokardial Akut (IMA) yang terkait dengan infeksi Chlamydia pneumoniae dan adanya infeksi multiple dengan mikroorganisme lain yang diduga dapat menyebabkan IMA. Malang: Pasca Sarjana Universitas Brawijaya. 2001.

15. Ciervo A, Visca P, Petrucca A, Biasucci LM, Maseri A, Cassone A. Antibodies to 60-Kilodalton Heat Sock Protein and Outer Membrane Protein-2 of Chlamydia pneumoniae in Patients with Coronary Heart Disease. Clinical and Diagnosis Laboratory Immunology, 2002; 9(1): 66-74

16. Kuo A, Sukhova GK, Lichtman AH, Libby P. Chlamydial HeatShock Protein 60 Localize in Human Atheroma and Regulates Macrophage Tumor Necrosis Factor- $\alpha$ and Matrix Metalloproteinase Expression. Circulation; 1998; 98: 300307. 

Murwani, dkk., Identifikasi Imonogenik Chlamydia pneumoniae ..... 